Gabriella SCHUBERT*

Friedrich-Schiller-Universität

Jena
Оригинални научни рад

Примљен: 21. 10. 2016.

Прихваћен: 10. 02. 2017.

\title{
СТАНИСЛАВ ВИНАВЕР О НЕМЦИМА
}

\begin{abstract}
Мој допринос је посвећен есејима српског писца Станислава Винавера (1891-1955) које је написао 1924. године, под насловом Немачка у врењу. У шест текстова Винавер разматра општу ситуацију у Немачкој после Првог светског рата, у Вајмарској Републици, и даје своје утиске о духовном и културном животу Немаца, а што је још важније, пише и о њиховом менталитету. Стога су ови текстови значајни из неколико аспеката: најпре из угла историјских докумената, затим из културолошко-имаголошких и књижевно-естетских перспектива, али и других разлога који се могу у њима истражити.

Кључне речи: Станислав Винавер, менталитет Немаца, Вајмарска Република, Срби о Немцима, есејистички стил Винавера.
\end{abstract}

Велики писац прве половине 20. века, Станислав Винавер, добро је познавао Немачку и одлично је савладао немачки језик. Боравио је у Немачкој неколико пута у различитим својстима - као туриста, новинар у дипломатској служби и заробљеник немачких нациста. Постављен је 1929. године за дописника Одељења за штампу при Краљевском посланству у Берлину. У Немачкој је остао, као службеник Централног пресбироа Председништва Министарског савета, све до 1934. године. ${ }^{1}$ На његово место, 1936. године, дошао је (по други пут) његов књижевни пријатељ Милош Црњански. Боравци и служба у Немачкој оставили су дубок траг на Винавера. О свему шта је тамо видео и доживео, писао је извештаје и есеје; ништа није оставио без коментара и оцена. Касније, међутим, имао је болно искуство са Немцима. Као официра бивше Југословенске армије у Другом светском рату, Немци су га заробили у априлу 1941. године и возом транспортовали у заробљеништво. Ратне године је провео у немачком логору Оснабрик, о чему је писао, између осталог, у књизи Године понижења и борбе, живот у немачким 'офлазима' (Београд 1945).

\footnotetext{
*gabriella.schubert@gmx.de

${ }^{1}$ О томе детаљније Булајић 2002.
} 
Мој допринос је посвећен есејима Винавера које је под насловом Немачка у врењу написао 1924. године. У шест текстова Винавер разматра општу ситуацију у Немачкој после Првог светског рата, у Вајмарској Републици и даје своје утиске о духовном и културном животу Немаца, а што је још важније, пише и о њиховом менталитету. Стога су ови текстови значајни из неколико аспеката: најпре из угла историјских докумената, затим из културолошко-имаголошких и књижевно-естетских перспектива, али и других разлога који се могу у њима истражити.

Есејистика је најзначајнији део Винаверовог књижевног рада. Његови есеји су јединствени у садржајном, као и стилском погледу. Основне карактеристике ових есеја јесу њихов отворен начин писања и изразит субјективизам. У свом уметнички и интелектуално захтевном приказивању Винавер не тежи да систематски и до корена анализира феномене које доживљава, него им се више мозаично, лежерно и асоцијативно приближава са разних страна. Ипак се труди да читалац схвата његова виђења без потребе да их генерализује. Винавер пише о свему што запажа и што му пада на ум са лакоћом, готово играјући се, духовито, луцидно и динамично, час са емотивном дистанцом, час са емпатијом и страшћу, а понекад и са иронијом. Дубоке мисли се мешају са тривијалним. Читалац се осећа увучен у његове мисли и емоције, опијен необичним асоцијацијама и неочекиваним сликама у којима се неки пут служи музичким, математичким и синестетским поступком. Сви његови текстови се одликују богатом ерудицијом и експресивним, визуелним изразом. Признато је у научним радовима ${ }^{2}$ да су његов стил и његово схватање језика најоригиналнији у српском модерном песништву.

У есеју „Немачка у врењу” Винавер доживљава једну земљу која се налази на прекретници: пораз Немачке у Првом Светском рату и Новембарска револуција 1918/1919. године против монархије, довели су до прогнанства кајзера Вилхелма II, али у исто време до инфлације и кризе у земљи. Глад и беда последњих ратних година и финансијски скандали 1923. и 1929. године повећавали су неповерење великог дела становништва према влади Вајмарске републике. Генералфелдмаршал Хинденбург је одредио судбину земље.

Овакву ситуацију, у којој се Немци плаше будућности, Винавер описује у првом есеју, под насловом „Добошари у ноћи”.

Налази се у Минхену. Посећује књижару, иде код берберина, слуша научно предавање и учествује у позоришном догађају. У тим приликама разговара са мештанима како би упознао њихов начин мишљења и уопште живота. При томе себе представља као комунисту и примећује да и између Немаца има политичких симпатизера. Купује књигу Пропаст Запада и констатује да

2 Уп., између осталог, Брајовић 2015. 
„солидна, од армираног бетона, зграда царства Немачког се срушила”. Међутим, верује да за Немачку не важи пропаст, јер по његовим речима „талас историјског мора, закон ритма изнеће, избациће опет у вис Велику Немачку, über alles” и да ,за Немце ради Бог сам” (Винавер 1996: 174). Винаверово критичко виђење самоуверености Немаца и немачких политичара увек се до одређене мере налази на граници ироније.

Посебно је интересантан његов опис једног позоришног комада који се даје у „Münchener Kammerspiele”: Глумци „говоре комађем реченица, које бацају једни другима у лица. Над њима болесни црвен месец, у мукама се вије, као да се порађа. Људи вичу, плачу, муче једни друге, траже кривца" (Исто: 174). Затим Винавер додаје: „Све је у одломцима речи и мисли излишних, испалих, отпалих, недошлих људи. ... Тамни добоши, час продирно чујно, час једва приметно освајају бића и пределе језовитим маршем.” (Исто: 175). Бубњање добошара на сцени Винавера асоцира на несрећну прошлост Немачке.

После Минхена, Винавер борави у Берлину. Доживљава и описује „Берлин у магли”, који, по његовим речима, „тешко и чудновато дише од кнежева, царева, генерала, краљева, грофова, министара и војсковођа”. Ти гломазни споменици немачких великана који седе на коњима сугеришу прекомерно самопоуздање Немаца, њихову увереност у своју супериорност. Гледајући њих, он је такорећи савладан негативним емоцијама кад пише: „И сви ови генерали и кнежеви са батинама, на грдним коњима, појављују се из магле, и прете сунцу да се не појави, да не покаже да су сви људи равни и слободни” (Исто: 179).

Сунце је из његове перспективе далеко на хоризонту и личи на једну поморанџу која „сасвим случајно обешена изнад видика улице, као лампион” (Исто: 176). Шетајући улицама Берлина, сећа се кад је на исти начин доживљавао друге градове у магли. Све у свему, слично Милошу Црњанском, који неколико година касније посећује Берлин ${ }^{3}$, Винавер се осећа некако изгубљено у велеграду. Са страхом, али можда до одређене мере и са иронијом, оцењује перфекцију Немаца. „Други народи”, пише Винавер, „са својим доживљајима, са својим страстима и грчевима дају само сировину, материјал који Немац има да сведе у категорије, да класификује у обрасце, да згрупише у редове и феле, и најзад да осмисли.” (Исто: 176-177).

У тумачења немачког менталитета постоји једна очигледна паралела између Станислава Винавера и Драгише Васића. Упадљиво је њихово осећање угрожености и несигурности, као и то да негују стереотипе, који су о Немцима и о Немачкој били проширени након Првог светског рата код Срба, али и

\footnotetext{
${ }^{3}$ Према опису Милоша Црњанског у путопису „Ирис Берлина” (1928). У вези са тим уп. Шуберт 2005.
} 
код других народа у Европи. У берлинској магли Винавер види „бескрајног Фридриха, на бескрајноме коњу, ... на бескрајним кљусинама”, који „чува друге улазе, чува све наше човечанске улазе" (Винавер 1996: 179).

Наравно, доживљај другости, односно разлике у менталитету, не мора увек бити предрасуда. Тако, на пример, Винавер осећа разлике у људским односима које опипљиво постоје у јужним и западним земљама Европе. Понашање Немаца не одговара његовом менталитету. По мишљењу Винавера, код њих „недостаје жива, животворна кап, оно нешто због чега све на крају крајева и јесте лепо или ма какво.” (Исто: 177). Њихов живот, по њему, „постаје препричан, преудешен и сажвакан, подељен у прегледне квадрате” (Исто: 177).

\section{III}

У трећем есеју, под насловом „Музички проблем Немачке”, Винавер долази до закључка да је музика централни проблем Немачке. Музику схвата у филозофском смислу, као израз душе. У том контексту упоређује особине различитих народа: Срба, Италијана, Руса и Немаца.

Нико по његовом мишљењу не може схватити Србију без косовске епопеје. Зато Винавер пише: „без Косова у монотономе, у дугоме, у непрекидноме десетерцу који, готово никад не подиже нагласак, јер је све подједнако трагично и судбоносно" (Исто: 180).

Италију, по Винаверу, нико не може разумети без њених великих уметника: Рафаела, Ђота, Тицијана и Леонарда. А за Француску, по њему, треба знати шта је и ко је био Наполеон и то да је он поставио јасне узвишене и разумљиве циљеве за сваког створа на овој „бесциљно хаотичној” планети. Русија Винавера асоцира на патњу Христа за правду на земљи.

Размишљајући о Гетеу, Шилеру, Ренану, Ромен Ролану, Шопенхауеру и њиховом односу према музици, Винавер стиже до централне поруке овог есеја, а то је да „Немачка пати од своје сопствене душе: од музике”. Сматра:

[Немачка] пати од прекомерног оваплоћења: музика не сме да буде крајњи израз, већ само игра око крајњега израза. А последње, има, мора и сме и може: само да се наслути. Саис. Нико, некажњено, не сме постати до краја, као што и нико, некажњено, не сме не постати собом - јер ће га други тад формирати (Исто: 183).

Критикује Винавер и неуморно музицирање Немаца у кафанама, које упоређује са њиховом потребом да организују, да уреде, да ускладе свет. Композиције Бетовена, Брамса и Баха из ове перспективе постају површно организоване радње. Разумљиво је да Винавер као темељни познавалац музике критикује кафанско музицирање; мање је, међутим, разумљиво да не разликује од кафанског музицирања светски квалитет композиција Бетовена, Брамса и Баха. 
У следећем есеју, под насловом „Створ који корача”, Винавер описује паничну атмосферу међу људима услед инфлације у Немачкој. Она је трајала од 1914. до 1923. године и била је једна од најрадикалнијих хиперинфлација великих индустријских нација. Узрок је финансирање Првог светског рата. Са крајем рата 1918. немачка марка је званично већ изгубила преко половине своје куповне вредности, а индекс инфлације на црној берзи је био знатно виши. После 1919. године држава је у великој мери проширила издавање новчане масе, како би поткрепила државне дугове, а тиме је немачка марка драматично девалвирала. Винавер у овом контексту извештава: „Свет још увек постоји. Земља се окреће. Сунце сија. Свет јесте како јесте - а марка ипак пада" (Исто: 185). Овог пута Винавер посматра реакцију и понашање људи, ипак, са саосећањем: „Овај радник није седам дана окусио месо. Све кромпир, чорба, лебац и пиво. И овај чиновник сања о свињетини. Ова мала мрзне се код своје куће. Тако је ладно" (Исто: 185-186).

С друге стране, Винавер критикује послушност Немаца, која је, по његовом мишљењу, узрок те ситуације. Експлозиван језички стил прати његов коментар у коме показује његово широко знање, а и његов експресионистички стил писања:

И страшно умире овај народ још и зато што је он својим царевима, чиновницима, поповима и генералима, својим вођама, председницима одбора и директорима свести и савести увек веровао, а још и данас верује. Државотворна вера у вође, вера у солидност управе, вера, ако хоћете да Немце и сам врховни поглавар, Немачки Бог (Исто: над-дворски тајни саветник, витез Олује и Громовне Круне и другог ордења, редовни професор и доктор теологије, господин фон Бог) - не може, не уме оставити. Откуд да би бог: солидан, наметан, силан - могао да постане вашарски шарлатан, подвалаџија из Хебеловог „Шацкестлајна”? (Исто: 187).

У том контексту Винавер пише о спекулантима-шиберима који купују и продају ствари, а од зараде добро живе и улажу у непокретности. О издржљивости Немца у тим тешким условима Винавер пише: „То је, можда, тајна немачке снаге, тајна зашто још нису пропали" (Исто: 188). Коментарише Винавер, између осталог, и поновну женидбу седамдесетогодишњег кајзера, годину дана после смрти царице. О томе пише: „Зар сад се женити, зар сад мислити на пир, кад све пропада" (Исто: 189). За будућност Немачке има застрашујућу визију, визију Роденовог створа, уп: „Роденов торсо који корача, али нема ни главу ни руке. En marche. ... Лагано и гломазно он иде. Ја чујем тешки топот његових корака. И оргију у Немачкој на све стране - његови мукли кораци дају, с времена на време, чудан и језовит такт” (Исто: 190).

У току читања Винаверових утисака о Немцима осећа се колико се труди да боље разуме њихов менталитет и понашање, али да му то врло тешко пада. 
У следећем есеју, под насловом „Кула бројева”, Винавер за оцену немачког менталитета има математички приступ. Повезује Немца са вавилонском кулом бројева и сматра да су куле бројева његови духови-чувари. Док би мање школован и учен народ побегао од куле бројева, ако се та кула случајно заљуљала, немачки дух, видевши да бројеви попуштају и варају, хоће да се спасава, али још увек помоћу бројева. Другим речима, немачки дух још увек стоји код своје напукле државне и духовне машине, „подешава, бремзује, звони на пажњу, тестерише, прекреће, пребацује, покушава и успева да спречи катастрофу, да искористи оно што је ту и како је ту, да не би и друго пукло и отишло у бездан" (Исто: 193).

Примећује Винавер код Немаца и једну челичну еластичност, коју упоређује са жилавом месом. „Још увек ови хладни и пажљиви људи, хладно и фанатично верују у своју машину, у своју историју са најмањим њеним циљем, у свој начин изградње и обуздавања свега што је искрсло и што ће искрснути у свету" (Исто: 194).

\section{VI}

У последњем есеју, под насловом „Стража на Рајни”, запажа понашање људи у ресторану. Са прецизношћу једног патолога описује како једу и пију. Пише:

Једу дубокомислено. Руке са ножем и виљушком раде као да су неки инжињери у фабрици. Гледао сам их кад пију. И то је нека дужност. И код седме кригле никад један гутљај да је само онако пијанички и чулан. То је један посао: посао испражњавања кригле. А свакоме послу приступа се са пажњом и страхопоштовањем (Исто: 195).

Наставља:

Тако пију кад их нико не гледа и кад су сами. А кад су у друштву, ту има условљеност дизања и спуштања и задржавања руке, и постоје књиге како се то пије: „Das Biercomment”. Хтео сам да запитам једнога: Mein Herr, јесте ли ви попили криглу пива - или само испразнили толико и толико кубних милиметара такве и такве течности, која вам на такав начи прија, а с помоћу таквих и таквих покрета? Нисам могао да одолим: приступам. А питам, шта сам намерио. Разуме се, нашао сам учтив начин за питање. Господин је био неки доброћудни професор. Он ми одговара: кад не би било начина, покрета, свести о начину и покрету и знања о њима: откуд бих ја, најзад знао да је то пиво? Сва та сценарија повећава моје задовољство - штавише чини га могућим. Нећете ваљда да испитујем пиво без побожности, како какав безбожни Француз. Шта је Бог да нешто нема побожности са којом му идемо у сусрет? (Исто: 196)

Винавер закључује: „Дакле - наш рад и нерад, наше гутање алкохола и једење, и путовање: без побожности су. Сувише имају у себи логичке брзине, математичке прегледности. А са пуно дубокомислене дубине Немци прилазе свету. Све је подједнако важно и побожно" (Исто: 196). 
Читалац се пита: да ли Винавер таквим оценима жели да изрази своје поштовање или, ипак, иронију према Немцу?

У следећем упоређује Французе са Немцима. Сматра да Немци дубокомисленом темељношћу оперишу да је њихов доказ „у дубини, испод земље”. Насупрот томе, Французи су по њему једнострано логични. Они су народ који даје доказ у висину, изнад. Код Француза је, по речима Винавера, „све унапред већ доказано, а код Немаца - накнадно".

У даљем тексту се бави односом Француза и Немаца, односно свађом која се развијала између француског писца Бориса Бареса и немачког професора Бертрама. Журналиста и писац Борис Барес је био један од највећих шовиниста Француске тог времена, који је мрзео Немце и хтео да докаже како су Немци срцем и душом скривени Французи и да их зато треба, ма и силом, и против њихове воље начинити Французима. По извештају Винавера, Барес сматра да немачка митологија нема везе са Рајном. Винавер ову њихову свађу коментарише речима: „И тако се бију француски дух и немачка темељност" (Исто: 200). Винавер је једнако добро познавао Французе и Немце, јер је, између осталог, боравио као дипломата и у Француској. Зато је био у стању да оцени ширину дејства немачке културе у Француској. Тако закључује да су „Вагнер и Ниче више можда дејствовали на Француску но и на немачку интелигенцију" (Исто: 200). Посматрајући како се гложе Французи и Немци, Винавер суверено констатује: „оно што је највеће до данас дала Европа: француски дух и логика, и немачка темељност” (Исто: 201).

У том тренутку се ипак појављује његов осећај инфериорности. Пише: „дође нам нека туга. Нека тешка туга нама, који смо им се дивили, јер нисмо могли доћи на загушљивоме Балкану до њихове ведре и широке мисли" (Исто: 201).

На крају се то осећање претвара у своју супротност. Самосвесно, тријумфално пише:

И ми почињемо, верујте, по каткад, да боље разумевамо и те Немце и те Французе, и сву ту Европу, боље но они сами. Јер су нам се неочекивано приближили. Јер су, гле, гле! неочекивано, они почели, стицајем неких сличних, мада џиновских прилика, да постају Балканци (Исто: 202).

Уместо опширнијег закључка рекла бих на крају да су Винаверове мисли о западној Европи и његове оцене Немаца и данас актуелне и заслужују да се о њима размишља. Зато би било од велике користи да се у Немачкој читају Винаверови есеји у немачком преводу. 


\title{
ЛИТЕРАТУРА
}

Брајовић 2015: Т. Брајовић, Станислав Винавер као поетички волшебник српског модернизма, у: П. Петровић (ур.), Поезија и модернистичка мисао Станислава Винавера. Поетичка истражсивања, књ. 20, Београд: Институт за књижевност и уметност, Шабац: Библиотека шабачка, 112-126.

Булајић 2002: В. Булајић, Станислав Винавер у Берлину. Из извештаја дописника Централног пресбироа 1929-1934, Архив. Часопис Архива Југославuje, 3, 109-120.

Винавер 1996: С. Винавер, Немачка у врењу, у: Милорад Софронијевић и Миодраг Максимовић (пр.), Срби о Немиима, Београд, 173-202.

Шуберт 2005: Г. Шуберт, Слика Црњанског о Немцима у путопису „Ирис Берлина" и у његовим политичким коментарима, Научни састанак слависта у Вукове дане, 34/2, 301-312.

\author{
Gabriella Schubert
}

\section{STANISLAV VINAVER ÜBER DIE DEUTSCHEN}

(Zusammenfassung)

Mein Beitrag widmet sich den Essays des serbischen Schriftstellers Stanislav Vinaver (18911955), die er unter dem Titel Nemačka u vrenju [Deutschland in Aufruhr] im Jahr 1924 verfasste. In sechs Texten betrachtet Vinaver die allgemeine Lage in Deutschland nach dem Ersten Weltkrieg, in der Weimarer Republik, und gibt seine Eindrücke über das geistige und kulturelle Leben der Deutschen wieder; mehr noch, er beschreibt seine Sicht ihrer Mentalität. Aus diesem Grunde sind diese Texte unter verschiedenen Aspekten von Bedeutung: vor allem als historisches Dokument, ferner aus kulturwissenschaftlich-imagologischer und literarisch-ästhetischer Perspektive, aber auch in anderen Kontexten, die in ihnen untersucht werden können. 